\title{
EL SANTUARIO DE NUESTRA SEÑORA DE REGLA EN LA RESTAURACIÓN DE LAS ÓRDENES RELIGIOSAS EN ESPAÑA (1880-1882)
}

\author{
Jorge Alberto Jordán Fernández \\ Doctor en Historia
}

\section{RESUMEN / ABSTRACT}

En este artículo se estudia el papel jugado por diferentes órdenes religiosas con vistas a la instalación de alguna de sus comunidades en el antiguo cenobio agustino de Nuestra Señora de Regla sito en la localidad gaditana de Chipiona en el marco del proceso de restauración de las órdenes religiosas vivido en España tras la supresión de las mismas, sobre todo con la llegada al trono español del rey Alfonso XII en 1875, proceso que se vio complicado por la instalación en nuestro país de las comunidades religiosas expulsadas de Francia a partir de 1880. Se analiza especialmente el papel desempeñado por los franciscanos misioneros españoles y los monjes benedictinos franceses de las abadías de Solesmes y Ligugé.

In this paper we study the role played by different religious orders in order to be established in the old Augustiniansconvent of NuestraSeñora de Regla in the town of Chipiona. The process is rooted during the restoration process of religious orders after their cancellation, a process that was difficult-especially after the crown of King Alfonso XII in 1875- because of the arrival to Spain of French communities being putting out from France in 1880. Specifically, we study the role played by Franciscan Spanish missionaries and Benedictines French monks from abbeys of Solesmes and Ligugé. 


\section{INTRODUCCIÓN}

Echamos en falta en la historiografia actual una monografia que proporcione una visión de conjunto sobre el proceso de restauración de las órdenes religiosas en España tras la exclaustración general decretada en 1836, parecida a la que en su día hizo el profesor Revuelta para el proceso de exclaustración vivido en nuestro país en el primer tercio del siglo XIX. ${ }^{1}$ Actualmente se cuenta con muchas visiones parciales de este proceso de restauración, bien referidas a una orden religiosa en concreto o bien a un área geográfica determinada. ${ }^{2}$

El trabajo que hoy presentamos nace con la pretensión de convertirse en una aportación más a ese amplio elenco de visiones parciales acerca del interesante tema de la restauración religiosa en España. Para ello nos acercamos al papel que desempeñó en el proceso de la restauración religiosa uno de los antiguos edificios monacales que había sobrevivido al gran expolio sufrido por estos edificios tras la desamortización de los mismos: nos referimos al santuario de Nuestra Señora de Regla, situado en la población gaditana de Chipiona y que hasta la exclaustración había sido morada de una comunidad de religiosos agustinos; en las páginas que siguen veremos la estrategia seguida por las órdenes religiosas interesadas en la instalación de sus religiosos en ese santuario, especialmente los franciscanos españoles misioneros de Tierra Santa, quienes finalmente conseguirian fundar en dicho lugar, y los benedictinos franceses expulsados de su pais, muy bien situados en la carrera final hacia la posesión del santuario,

Manuel REVUELTA GONZÁLEZ, La Exclaustración (1833-1840), Madrid, 1976.

A título de ejemplo mencionamos los siguientes trabajos: Juan CIUDAD GÓMEZ, Historia de la restauración de la Orden hospitalaria de San Juan de Dios en Espa$\tilde{n} a$, Granada, 1968; Serafin HUERTA, ocd, Los Carmelitas Descalzos en Andalucía (1893-1970), Sevilla, 1970; Gaspar CALVO MORALEJO, ofm, La restauración de la Orden Franciscana en España (1836-1856), Santiago de Compostela, 1985; Álvaro HUERGA, Los dominicos en Andalucía, Sevilla, 1992, especialmente pp. 221 y ss.; Francisco CANO MANRIQUE, Historia de la Orden de la Merced Descalza. La Restauración de la Orden (1886-1915), Madrid, 1992, vol. II; Ismael MARTÍNEZ CARRETERO, Exclaustración y restauración del Carmen en España (1771-1910), Roma, 1996; Manuel MARTÍN RIEGO, "Exclaustración y restauración en la archidiócesis de Sevilla (1835-1909). El caso de los Minimos”, en Isidorianum, 19 (2001) pp.179-235; ID, "Exclaustración y restauración de la Congregación del Oratorio de San Felipe Neri de Sevilla (1836-1876)", en Memoria Ecclesiae, XXIII (2003), pp. 231-258. 
como tendremos ocasión de comprobar; de paso, diremos algo también acerca de otras órdenes y congregaciones religiosas que se interesaron en algún momento por establecer allí una fundación.

\section{EL SANTUARIO DE REGLA TRAS LA EXCLAUSTRACIÓN ${ }^{3}$}

En 1835 los religiosos agustinos, que hasta entonces habian morado en este monasterio, se vieron obligados a abandonarlo por obra de las disposiciones de supresión general de las órdenes religiosas que entonces se promulgaron; sus bienes y rentas fueron aplicados a la Nación, mientras que la iglesia y sus objetos de culto quedaban a disposición del ordinario, en este caso, el arzobispo de Sevilla. La imagen de la Virgen de Regla fue trasladada a la iglesia parroquial de Chipiona, y allí colocada en un altar costeado a expensas de un devoto el año 1836, quedando desde entonces abandonado el antiguo santuario, que comenzó a vivir un proceso de ruina con el correr de los años.

En este estado de abandono permaneció el antiguo monasterio agustino hasta que en julio de 1851 fue visitado por los duques de Montpensier, ${ }^{4}$ quienes, ante tanta desolación determinaron poner

3 Seguimos en este apartado a Fr. Manuel Pablo CASTELLANOS, ofm, Relato histórico de Nuestra Señora de Regla, seguido de la Novena a su preciosa imagen, Cádiz, 1892; el P. Castellanos pudo recoger testimonios de primera mano de los acontecimientos que aquí se van a narrar, pues llegó al Santuario en 1882, con los primeros religiosos franciscanos, y su obra debió estar escrita muchos años antes como lo atestigua la aprobación de la misma que figura en el texto, datada en Madrid el 21 de marzo de 1887. Por lo demás, el P. Castellanos (1843-1911), natural de Priego (Cuenca), tomó el hábito en 1858 en el convento-colegio de su pueblo natal y fue uno de los Religiosos más sabios que ha tenido la Orden Franciscana desde su restauración, comenzada en Priego; cfr. Pedro CRUZ OCAÑA, Convento de San Miguel de las Victorias de Priego (Cuenca), Cuenca, 1929, pp. 115-116.

4 Están pendientes de estudio las vinculaciones de los duques de Montpensier con el proceso restaurador de las órdenes religiosas en España en esta época, tanto francesas como españolas, algunas de cuyas actuaciones van a salir en estas páginas, así como también su labor como mecenas en la reparación de conventos e iglesias; sobre esto último, cfr. Noticia del origen de la Capilla Real de la Virgen de Valme, labrada por el rey Fernando el Santo en 1248, y de su restauración, hecha por SS. AA. RR. los Serenísimos Señores Infantes Duques de Montpensier en 1859, Sevilla, 1859 (edición facsímil: Dos Hermanas, 1994). 
fin al destierro de la Virgen, concibiendo el piadoso proyecto de restaurar la iglesia, volver la imagen santa a su casa y poner un capellán para cuidar del culto de la Señora y del aseo del templo. ${ }^{5}$ Para llevar a cabo este santo propósito, los duques solicitaron la pertinente licencia al gobierno de Madrid, $y$ vencidas no pocas dificultades, lograron por fin la deseada licencia. ${ }^{6}$ En el orden material, encabezaron los duques una suscripción abierta para sufragar los costes necesarios para la reparación del templo y vivienda del capellán y para el traslado de la imagen de la Virgen con la debida pompa y solemnidad; en esta suscripción participó también con importantes sumas el entonces arzobispo de Sevilla, don Judas José Romo y Gamboa (1847-1855).

Reparado el templo y el camarín de la Virgen hasta donde alcanzaron los recursos allegados por los benefactores, en la tarde del día 7 de septiembre de 1852 se procedió al solemne traslado de la venerada imagen a su antigua morada desde la iglesia parroquial de Chipiona. A partir de entonces, el santuario quedó al cuidado de un capellán, cargo que, durante los primeros años fue ocupado por religiosos agustinos exclaustrados que habian sido hijos de este monasterio; así, el primero de que se tiene noticia fue el $\mathrm{P}$. Castro, a quien poco tiempo después sucedió el P. Domingo Dávila, que en los 19 años que estuvo al frente del santuario, hasta el de 1871 en que falleció, desplegó toda su actividad para fomentar el culto y la veneración a la Santisima Virgen. ${ }^{7}$ Al P. Dávila sucedieron otros capellanes que cuidaron del santuario en la medida de sus posibilidades y mantuvieron el culto a la Virgen de Regla, aunque no con el esplendor y solemnidad [con] que se hacía en los tiempos anteriores a la exclaustración de los religiosos, ni el fervor de los fieles y devoción a la Virgen eran como cuando habia Comunidad en el Santuario. ${ }^{8}$

CASTELLANOS, ob. cit., p. 57.

Ibídem.

CASTELLANOS, ob. cit., p. 61; incluso en 1867 se constituyó una hermandad de Ntra. Sra. de Regla, cuyos estatutos fueron aprobados por el arzobispado hispalense al año siguiente.

8 Ibídem, p. 62. 


\section{LA RESTAURACIÓN DE LOS RELIGIOSOS EN ESPAÑA}

Ya en el mismo decreto de extinción general de todos los monasterios, conventos, colegios, congregaciones y demás casas de religiosos de ambos sexos promulgado en 1836 se establecian varias excepciones a esta norma general, entre las que se encontraba la de los colegios de misioneros para las provincias de Asia de Valladolid (agustinos ermitaños), Ocaña (dominicos) y Monteagudo (agustinos recoletos), los cuales subsistirian con la denominación de Colegios de la Misión de Asia y quedarian bajo tutela del gobierno en cuanto a número de individuos de cada colegio, lo correspondiente a su buen régimen y lo relativo a admisión de novicios. ${ }^{9}$ Dicha excepción permitió, pues, la presencia de miembros de estas tres órdenes religiosas en el país aunque con no pocas limitaciones. Por su parte, la ley general de exclaustración de 29 de julio de 1837 establecía otra excepción a la norma general en su artículo $7^{\circ}$ : El Gobierno adoptará las disposiciones convenientes para la conservación y arreglo de los conventos y colegios de los Santos Lugares de Jerusalén y sus dependencias, disposición imprecisa de la que procederá el posterior reconocimiento de la orden franciscana en nuestra patria tras la exclaustración. ${ }^{10}$

El lento proceso de restauración de los regulares en España, que comenzaría algunos años después de estas disposiciones, conoció avances y retrocesos, dependiendo del signo, conservador o progresista, de quien gobernase la nación en cada momento. ${ }^{11}$ Así, durante el gobierno del moderado Narváez (1844-1854), se firmó un concordato entre España y la Santa Sede el 16 de marzo de 1851, concordato que posteriormente sería promulgado legislativamente

$9 \quad$ F. Javier CAMPOS Y FERNÁNDEZ SEVILLA, osa, "Textos legales de las desamortizaciones eclesiásticas españolas y con ellas relacionados", en VV. AA., La Desamortización. El expolio del patrimonio artístico y cultural de la Iglesia en España. Actas del Simposium 6/9-IX-2007, San Lorenzo del Escorial, 2007, p. 17.

10 CALVO MORALEJO, Ob. cit., p. 108.

11 Para hacernos una idea de lo cambiante del proceso puede valer el ejemplo de la Congregación del Oratorio de San Felipe Neri de Sevilla: suprimida en 1836, fue restaurada en 1852 y vuelta a suprimir en 1854; la revolución de 1868 trajo como consecuencia la destrucción de su casa e iglesia y hasta 1875 no pudo reunirse de nuevo la congregación; cfr. MARTÍN RIEGO, Exclaustración y..., ob. cit., pp. 208-213. 
en octubre de ese mismo año en forma de real decreto; ${ }^{12}$ con este instrumento legal se abrió el portillo para la vuelta de los religiosos a sus antiguos claustros, merced a la ambigua redacción dada a su artículo 29, según el cual, el gobierno se comprometía a mejorar oportunamente los colegios de misiones para Ultramar y a facilitar legalmente el establecimiento de casas y congregaciones religiosas de San Vicente de Paúl, San Felipe Neri y otra orden de las aprobadas por la Santa Sede. ${ }^{13}$

En desarrollo de esta disposición legal se dictaron posteriormente otras, como la del 23 de julio de 1852 que restablecía la congregación de San Vicente de Paúl o la del 3 de diciembre de ese mismo año que hacía lo propio con la de San Felipe Neri; ${ }^{14}$ y al no fijarse claramente cuál fuera esa otra orden, fueron varios institutos religiosos los que intentaron su restablecimiento.

Por real orden de 19 de octubre de 1852 se disponia, entre otras cosas, la fundación de un colegio de misioneros franciscanos para Filipinas, con las mismas caracteristicas de los otros tres ya existentes, que fue establecido en Aranjuez; ${ }^{15}$ el restablecimiento en Loyola de la Compañia de Jesús, también como colegio para las misiones de Filipinas; y el restablecimiento de un Vicario General

12 Ya antes de la firma de este concordato el gobierno había reconocido mediante un decreto a los escolapios como instituto religioso, decreto que fue publicado en marzo de 1845 y cuya promulgación se debió a la iniciativa del escolapio P. Cayetano Losada, rector del colegio San Fernando de Madrid; cfr. REVUELTA GONZÁLEZ, ob. cit., pp. 465-466.

13 Dice así dicho artículo (la negrita es nuestra): A fin de que en toda la Península haya el número suficiente de ministros y operarios evangélicos (...), el Gobierno de S. M., que se propone mejorar oportunamente los colegios de misiones para Ultramar, tomará desde luego las disposiciones convenientes para que se establezcan donde sea necesario, oyendo previamente a los prelados diocesanos, casas y congregaciones religiosas de San Vicente de Paúl, San Felipe Neri y otra orden de las aprobadas por la Santa Sede, las cuales servirán, al propio tiempo, de lugares de retiro para los eclesiásticos, para hacer ejercicios espirituales y para otros usos piadosos.

${ }^{14}$ Cfr. Vicente CÁRCEL ORTÍ, "El liberalismo en el poder (1833-68)", en VV.AA., Historia de la Iglesia en España, Madrid, 1979, t. V, pp. 154-158.

15 En enero de 1853 comenzó la andadura de este nuevo colegio en Aranjuez, de donde fue trasladado a Pastrana en junio de 1855; cfr. CALVO MORALEJO, ob. cit., pp. 225-226. 
residente en la Peninsula, para cada una de las órdenes religiosas de Agustinos Calzados, Agustinos Recoletos, Dominicos y Franciscanos Descalzos, de esas misiones. ${ }^{16}$

E1 26 de noviembre de 1852, la reina Isabel II firmaba una real cédula autorizando la creación de un nuevo colegio de misioneros con destino a Tierra Santa y Marruecos, zonas de interés estratégico para la politica exterior española, encargando del mismo a los franciscanos observantes, pues según se afirma en la mencionada disposición ningún instituto puede ser más a propósito que el de los hijos de San Francisco, dada su trayectoria anterior a la exclaustración. A los siete meses, otro real decreto, de 24 de junio de 1853, disponía, entre otras cosas, la creación del consulado español en Jerusalén encargado de entenderse con los religiosos franciscanos españoles residentes en Palestina (art. 1) y determinaba que previos los informes convenientes sobre la elección de sitio y demás que corresponda, se destinará a la mayor brevedad posible una casa para la admisión y educación de Misioneros Franciscanos con destino a Tierra Santa (art. 7). En desarrollo de esta disposición legal, una real orden de 19 de octubre de dicho año autorizaba la apertura de un colegio para la educación de misioneros franciscanos con destino a Tierra Santa en el antiguo convento franciscano de San Miguel de la Victoria de Priego (Cuenca). ${ }^{17}$ La fundación de este colegio misionero, sin embargo, no tuvo lugar hasta el 12 de julio de 1856, siendo trasladado seis años después, en septiembre de 1862, a Santiago de Compostela. ${ }^{18}$

Durante el llamado bienio progresista (junio 1854- julio1856) el proceso de restauración sufrió un parón, del cual puede ser indicativo la derogación mediante decreto de 11 de septiembre de

6 CALVO MORALEJO, ob. cit., pp. 128-129.

17 Cfr. Fr. Miguel VALLECILLO MARTÍN, ofm, "El P. Lerchundi y los Colegios de Santiago y Chipiona", en Archivo Ibero-americano, (1996) n $\mathrm{n}^{\circ}$ 223-224, p. 816-818. Calvo Moralejo da como fecha del decreto el 6 de octubre de 1853 (ob. cit., p. 152).

18 Cfr. CRUZ OCAÑA, ob. cit., pp. 100-103. Este convento debe considerarse con justicia como el origen en gran parte de la restauración de nuestra Orden en España, dirá el P. Francisco Ferrando en 1916, en la p. 40 de sus Apuntes históricos relativos al Colegio de PP. Misioneros Franciscanos de Santiago (la cita en VALLECILLO MARTÍN, ob. cit., p. 821). 
1854 de otro anterior, fechado el 3 de mayo de ese año, por el que se autorizaba el restablecimiento de una comunidad de monjes jerónimos en el monasterio de El Escorial. ${ }^{19}$

El siguiente periodo de gobierno, de signo moderado, encabezado por O' Donell y Narváez (1856-1868), que abarcó prácticamente hasta el final del reinado de Isabel II, supuso un nuevo periodo de expansión para las órdenes religiosas, como lo demuestran ciertas estadísticas relativas a esos años; así, para finales de 1867, los paúles contaban con 6 casas abiertas y 83 religiosos; los filipenses con 7 casas y 50 miembros; los agustinos calzados con dos casas y más de 150 religiosos; los agustinos recoletos con 2 casas y 166 miembros; los dominicos con dos casas en que moraban más de 160 religiosos; los franciscanos descalzos tenian abiertas tres casas con 113 religiosos y los jesuitas cinco casas, con más de 220 miembros. ${ }^{20}$

Los años siguientes (1868-1874), bastante azarosos en lo político, fueron de verdadero caos para el tímidamente comenzado proceso de restauración de los religiosos en nuestro país. ${ }^{21}$ Durante la revolución gloriosa de 1868, primero, se suprimió la compañía de Jesús, por decreto de 12 de octubre de 1868, y después, por decreto de 18 del mismo mes y año, fueron extinguidos todos los monasterios, conventos, colegios, congregaciones y demás casas de religiosos de ambos sexos fundados en la Peninsula e islas adyacentes desde el 29 de julio de 1837, incluyendo ahora tanto a los paúles como a los filipenses; sin embargo, la aplicación práctica de alguna de estas medidas, dictadas bajo la presión y las amenazas de las juntas revolucionarias, se suavizó en otras posteriores,

19 Cfr. CÁRCEL ORTÍ, ob. cit., p. 160.

20 Los datos en CÁRCEL ORTÍ, ob. cit., p. 220, donde se recoge en un cuadro las Casas religiosas de varones entre 1859 y 1867 según las "Guías del Estado Eclesiástico" y en otro el número de religiosos en clausura que existían en los conventos de la peninsula e islas adyacentes en fin de 1867. No hacemos referencia a los datos de escolapios y redentoristas, que abultarian aún más las cifras expuestas; por otro lado, resulta obvio que en estos datos se incluyen los colegios de misiones de agustinos de ambas órdenes, dominicos y franciscanos.

21 En tan corto espacio de tiempo tuvieron lugar una revolución (1868-70), una monarquía (1871-73) y una república (1873-74), por lo que las medidas de uno y otro signo se sucedieron unas a otras sin que su efectividad real pueda ser calibrada adecuadamente de un modo general. 
cuando fueron suprimidas dichas juntas. ${ }^{22}$ En cualquier caso, esta supresión no afectó a los colegios de misiones, los cuales, como dijo el franciscano P. Lerchundi, según veremos después, fueron siempre respetados hasta por los revolucionarios más furiosos. ${ }^{23}$

Finalmente, el proceso restaurador vivió una época especialmente fecunda para el desarrollo de la vida religiosa durante el reinado de Alfonso XII (1875-1885), y la regencia de su viuda, María Cristina (1885-1902), periodo durante el cual clero regular y congregaciones religiosas conocerán su mayor auge del ochocientos, en palabras de Cuenca Toribio. ${ }^{24}$

\section{LOS FRANCISCANOS ESPAÑOLES MISIONEROS DE TIERRA SANTA}

Una de las primeras órdenes religiosas interesadas en establecerse en el antiguo cenobio agustino de Nuestra Señora de Regla fue la de los franciscanos, especialmente sus misioneros destinados en Tierra Santa, quienes finalmente consiguieron su objetivo gracias a los desvelos y esfuerzos desplegados por el P. José Lerchundi. ${ }^{25}$ Esta fundación, andando el tiempo, se convertiría en la cabeza de una futura provincia franciscana española.

Acerca de cómo fueron a parar los franciscanos misioneros a dicho santuario, reproducimos la sucinta a la par que ilustrativa versión del P. Castellanos: ${ }^{26}$

22 CÁRCEL ORTÍ, Vicente, "La revolución burguesa (1868-74)", en VV.AA., Historia de la Iglesia en España, Madrid, 1979, t. V, pp. 235-236, quien afirma que a los jesuitas se les permitió regresar a sus colegios, pero sin usar el hábito talar.

23 La cita en VALLECILLO MARTÍN, ob. cit., p. 875, n. 143, en carta dirigida al arzobispo de Sevilla.

24 CUENCA TORIBIO, José Manuel, "El catolicismo español en la Restauración (1875-1931)", en VV.AA., Historia de la Iglesia en España, Madrid, 1979, t. V, pp. 278-279.

25 El P. José Lerchundi (1936-1896) tomó el hábito en la orden franciscana en 1856 en el colegio misionero de Priego, siendo ordenado sacerdote en 1859; apenas dos años después, es destinado como misionero a Marruecos hasta que en 1877 las autoridades eclesiásticas lo nombran Pro-Prefecto de las misiones de Marruecos, no sin la oposición del gobierno español, que lo mantuvo desterrado de Marruecos hasta finales de 1879, puesto en el que se mantuvo hasta su fallecimiento.

${ }^{26}$ CASTELlANOS, ob. cit., pp. 63-64. 
... trataron los religiosos franciscanos de fundar un nuevo Colegio de Misiones para que, en unión del que ya tenian en Santiago de Galicia, pudieran tener suficiente personal para las Misiones a ellos confiadas en Tierra Santa y Marruecos. Debido a las gestiones de los religiosos, obtúvose una real orden del gobierno de Madrid, en la que se autorizaba al M.R. Prefecto de las Misiones de Marruecos, Fr. José Lerchundi, para buscar el Convento donde debia erigirse el nuevo Colegio. El Santuario de Ntra. Sra. de Regla fue el elegido para este fin; pues si bien el convento era sumamente pequeño y lo que aún quedaba de él amenazaba, según dejamos dicho, eminente ruina, la soledad y retiro del mismo se prestaban admirablemente a la contemplación y al estudio, (...). No dejaron de presentarse graves dificultades para la instalación del nuevo Colegio, pero la divina Providencia quiso que todas se vencieran sirviéndose de la actividad y diligencia de los religiosos, admirablemente secundadas por el Excmo. Sr. D. Jacobo Prendergast, jefe del departamento de la Obra Pía de Jerusalén, por cuya cuenta corría todo lo relativo al desarrollo material del Colegio, como destinado a las Misiones de Tierra Santa y Marruecos.

Más ampliamente se desarrolla esta cuestión en un trabajo publicado en la revista Archivo Ibero-americano por el también franciscano P. Samuel Eiján en 1945 bajo el título de El P. Lerchundi y la fundación del Colegio de Chipiona; ${ }^{27}$ en dicho trabajo, su autor afirma que con fecha de 10 de junio de 1880 se publicó una real orden en la cual se disponía lo que sigue: ${ }^{28}$

Necesitando un estudio muy detallado y entrañando mucha importancia para el desarrollo de las Misiones el establecimiento de un Colegio subordinado directamente del Pro-prefecto, se pidan a éste informes circunstanciados sobre el punto de instalación, que deberá ser cerca de Marruecos, condiciones con que sería cedido a los religiosos y gastos que pudiera ocasionar.

E1 Pro-prefecto era a la sazón el P. Lerchundi, quien en octubre de 1878 había sido nombrado rector del colegio de misiones de

27 P. Samuel EIJÁN, ofm, "El P. Lerchundi y la fundación del Colegio de Chipiona", en Archivo Ibero-americano, $\mathrm{n}^{\circ} 18$ (1945) pp. 145-171.

28 Ibídem, p. 150. Dos días antes había tenido lugar en Madrid una reunión de los franciscanos con representantes de la Obra Pía en la que se acordó definitivamente la fundación de un nuevo colegio, "hijo de Santiago", bajo la inspección directa del Prefecto, que habia de establecerse en cualquier punto de Andalucia, Valencia o Murcia; cfr. VALLECILLO MARTÍN, ob. cit., p. 857. 
Santiago y durante los ocho meses en que estuvo al frente del mismo es seguro se convenció de la imposibilidad de que un solo Colegio pudiera atender a todo y trató con la Comisaría [de Tierra Santa] de Madrid del establecimiento de nuevo Colegio en clima más benigno que el de Galicia; ${ }^{29}$ a finales del año 1879, estando Lerchundi de paso en Madrid para tomar posesión de su cargo de prefecto fue cuando logró convencer al Gobierno de la necesidad de nuevo Colegio. ${ }^{30}$

El 10 de julio de 1880, el P. Lerchundi recibía del Delegado del Comisario General de la Orden Franciscana la competente autorización poder fundar un Colegio franciscano destinado a las Misiones de Tierra y Marruecos en nuestro antiguo convento de La Rábida o en otro punto de Andalucia, Murcia o Valencia, concediéndole, al mismo tiempo, facultades necesarias para tratar este asunto con los Prelados eclesiásticos y regulares $y$, si fuere conveniente, con las autoridades civiles. ${ }^{31}$

Con el fin de poder evacuar los informes solicitados en la real orden mencionada más arriba, el P. Lerchundi solicitó autorización al gobierno para realizar un viaje de exploración; esta solicitud la realizó el día 16 de julio de 1880 y, ante la falta de respuesta, la reiteró tres días más tarde; en oficio posterior anunciaba su partida, sin comunicar el rumbo que toma en la misión confiada a su solicitud por el Gobierno y también por el delegado y visitador general de la orden franciscana en España, P. José $\mathrm{M}^{\mathrm{a}}$ Gallego, como hemos visto más arriba. ${ }^{32}$

Nos dice el P. Vallecillo que los primeros pasos de su expedición los encaminó el P. Lerchundi hacia el ex convento franciscano de La Rábida, entonces propiedad de la Diputación Provincial de Huelva, solicitándolo formalmente al presidente de esa corporación provincial; en un segundo momento, giró visita al ex convento de Loreto, cuyo informe acerca de su situación es mucho más positivo que el de La Rábida; y finalmente, visitó el santuario de

\footnotetext{
EIJÁN, ob. cit., p. 146.

Ibídem, pp. 149-150.

VALLECILLO MARTIIN, ob. cit., p. 861 y n. 112.

EIJÁN, ob. cit., p. 150.
} 
Nuestra Señora de Regla, que describió así en su informe dirigido al comisario de la Obra Pía: ${ }^{33}$

Después de haber informado a $V$. E. en mis dos oficios últimos acerca de los conventos de La Rábida y de Ntra. Sra. de Loreto, faltaria a mi deber si no llamase su atención hacia otro convento llamado de Ntra. Sra. de Regla. (...). Todo el edificio fue perfectamente restaurado a expensas de los Infantes Duques de Montpensier y por consiguiente, se conserva en el mejor estado posible, excepto una pequeña parte que quedó por restaurar. Todas las oficinas de este convento son más capaces que las de los otros ya expresados. En el noviciado, que es muy espacioso y se conserva en buen estado, se halla una celda que ocupó Santo Tomás de Villanueva, donde se ve un lienzo-retrato del santo y una lápida conmemorativa. (...). En resumen, el Convento de Regla, por su capacidad, posición y estado actual, es preferible a los otros. La reedificación de la parte arruinada costaría poco menos que las obras de los otros proyectos. El edificio es propiedad del Estado.

La visita al santuario de Regla fue realizada por el P. Lerchundi el 16 de agosto de 1880, junto a un acompañante, y guiados por el entonces capellán, don José Bustamante, quien según parece, le manifestó al visitante su deseo de que una orden religiosa se hiciese cargo del santuario; dos días después el P. Lerchundi remitía el informe a la Obra Pía en los términos que acabamos de ver, con lo que, de momento, concluyeron sus gestiones, pues al poco tiempo volvió a Tánger, pero no sus preocupaciones acerca de este asunto; así, el 24 de agosto de 1880, en contestación a una carta recibida de la Obra Pía, les dice lo que sigue: ${ }^{34}$

El capellán del Santuario me aseguró que los PP. Jesuitas procedentes de Francia desean apoderarse del convento y que al efecto, hace unos ocho dias mandaron comisionados para que se enteraran del estado en que se encontraba el edificio. Añadióme también que algunos PP. Agustinos exclaustrados de Andalucia hacian gestiones en el mismo sentido, advirtiendo a $V$. E. que el expresado capellán manifiesta públicamente sus simpatías e inclinación a los RR.PP. Jesuitas. Por consiguiente, si V. E. quiere que se establezca alli nuestro Colegio, convendrá que se gestione cuanto antes con el Ministerio de Hacienda la cesión de dicho convento.

\footnotetext{
33 Puede verse la cita completa y las gestiones realizadas por el P. Lerchundi más ampliamente en VALLECILLO MARTÍN, ob. cit., pp. 862-3 y n. 118.

34 VALLECILLO MARTÍN, ob. cit., pp. 867-8 y n. 123.
} 
Sin dilación se pusieron en marcha los trámites administrativos y así, el 30 de agosto, el Ministerio de Estado solicitaba al de Hacienda la cesión del santuario de Regla, por concesión de Alfonso XII. ${ }^{35}$

Por otra carta posterior, fechada en Tánger el 15 de septiembre de ese año y dirigida a la Obra Pía, el P. Lerchundi parece dar a entender que está a la espera de confirmación de su propuesta por parte de las autoridades civiles, para proceder a solicitar la autorización de las eclesiásticas correspondientes, pues, entre otras cosas dice lo que sigue: ${ }^{36}$

Cuando se ha de fundar un establecimiento religioso en una Diócesis, es necesario contar con la venia del Diocesano, según los Sagrados Cánones. Al pasar por Sevilla, no pude hablar con el Sr. Arzobispo, por hallarse ausente, y tuve que escribirle desde aqui. Hoy he recibido su contestación y adjunta remito a V. E. su copia. Si V. E. aprueba la fundación en $N^{a} S^{a}$ de Regla, como sitio que reúne las mejores condiciones, será doloroso que se apoderen de aquel edificio Religiosos que además de no tener estabilidad, probablemente serán franceses. Acudo a V. E. apresuradamente, a fin de que vea si se puede arreglar el asunto según nuestros deseos.

La carta del arzobispo de Sevilla, fray Joaquín Lluch, ${ }^{37}$ al P. Lerchundi que se menciona en la anterior comunicación lleva fecha de 13 de septiembre de 1880, es respuesta a una anterior del franciscano, fechada el 9 del mismo mes y año, y en ella le decía el arzobispo que los franciscanos serian recibidos con los brazos abiertos en la diócesis y que contase con su bendición y licencia para fundar en la Rábida o en Loreto, pero que el convento de Ntra. Sra. de Regla está ya destinado para otra Orden religiosa recomendada muy eficazmente por el Excmo. Sr. Infante Duque de Montpensier. ${ }^{38}$

En vista de este escollo, el P. Lerchundi remitió una nueva carta al arzobispo hispalense en 25 de septiembre, cuyo contenido exacto

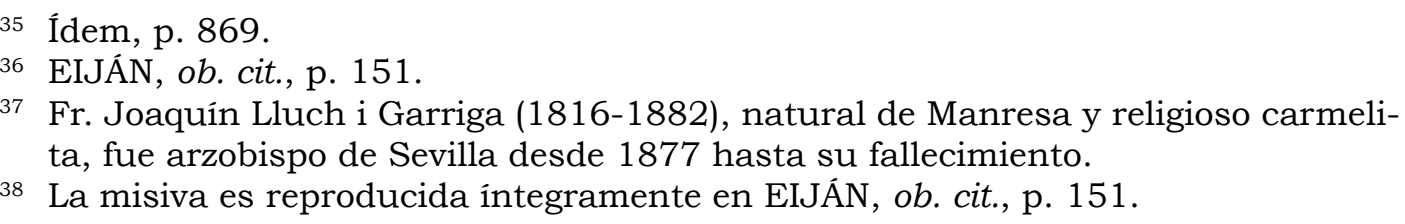


desconocemos, en la que, con el debido respeto, le exponía varias razones para inclinar su ánimo a favor de nuestra fundación, según los deseos del Gobierno y de la Comisaria de Tierra Santa; ${ }^{39}$ cuáles fueran las razones expuestas por el P. Lerchundi es algo que se nos escapa, pero no debían alejarse mucho de las expuestas por la Obra Pía en carta remitida a dicho padre, al tener conocimiento de la negativa del prelado sevillano a entregar el santuario a los franciscanos: ${ }^{40}$

Siento que este Sr. [el arzobispo de Sevilla] no esté dispuesto a conceder el convento de $N^{a} S^{a}$ de Regla para la fundación del colegio proyectado y que lo tenga ofrecido a otra Orden religiosa... Vuelva a escribir a dicho Sr. Arzobispo exponiéndole que, pedido al $M^{o}$ de Hacienda, la concesión no será dificil conseguirla, tratándose de una fundación permanente, como será la nuestra, y no de dudosa existencia, como sería la de cualquier otra Orden. Debe manifestarle que, ni La Rábida ni Loreto, nos conviene tanto como el de Regla, por su situación topográfica y demás condiciones... llevar la convicción al ánimo de su Señoría y accederá a nuestros deseos.

De todas formas, es posible que la mencionada carta del P. Lerchundi, fechada en 25 de septiembre, que hizo reconsiderar al arzobispo sevillano su decisión, fuera la siguiente, en la cual el franciscano hace valer el apoyo del gobierno a su fundación: ${ }^{41}$

... después de darle las más rendidas gracias porque se ha dignado darnos su bendición para fundar en La Rábida o en Loreto, debo poner en su conocimiento que antes recibi una comunicación del Ministerio de Estado manifestándome que (...) habian elegido el Colegio de Regla para nuestra

39 Cfr. EIJÁN, ob. cit., pp. 153-154. Esto en carta del P. Lerchundi a don Jacobo Prendergast, fechada en Tánger el 20 de octubre de 1880, en la que le daba cuenta de la favorable respuesta recibida del arzobispado hispalense y añadia: Ahora sólo resta que el Rvdmo. Albiñana arregle el asunto en Roma, como lo indica la expresada carta del Sr. Arzobispo, para que todo se haga canónicamente. Por cierto, en dicha carta se hace también referencia a una anterior, de fecha 25 de septiembre, remitida por Prendergast al P. Lerchundi, tal vez en respuesta a la que el día 15 de dicho mes le había enviado el franciscano y a la que nos hemos referido más arriba.

40 VALLECILLO MARTÍN, ob. cit., p. 872 y n. 135.

41 VALLECILLO MARTÍN, ob. cit., p. 875, n. 143; lo decimos con cautela toda vez que el P. Vallecillo no proporciona la fecha de la misma y ello hace que no podamos afirmarlo con rotundidad. 
fundación. Ignoro el objeto de los religiosos que quieren establecerse en Regla, pero si no son autorizados por el Gobierno para nuestras misiones extranjeras o ultramarinas, su fundación no puede ser tan permanente y estable como las nuestras, pues sabido es que, tanto nuestro Colegio de Santiago como los de Filipinas, han sido siempre respetados hasta por los revolucionarios más furiosos. Por esta consideración y por evitar complicaciones con el Gobierno, acudo a V.E.I. para ver si con su distinguido talento puede hallar algún medio para que nuestra fundación se verifique en Regla, según lo desea el Ministerio de Estado.

Las razones expuestas por el P. Lerchundi causaron el efecto deseado por éste para que el prelado hispalense se sintiese libre del compromiso contraido con el infante y con el nuncio, en virtud de fuerza mayor, y con lo cual se vencía su resistencia; de este modo, en una nueva misiva del arzobispo al P. Lerchundi, fechada en Sevilla el 11 de octubre de 1880, se avenía a la solicitud del franciscano, con las siguientes palabras: ${ }^{42}$

He recibido la apreciable carta de V., fecha 25 de septiembre último, y enterado de su contenido, debo decirle que, a pesar de haberse concedido a esta jurisdicción el Convento de Ntra. Sra. de Regla para el Santuario del mismo nombre por S. M. la Reina $D^{a}$ Isabel $2^{a}$, en sus Reales Órdenes comunicadas por el Ministerio de Gracia y Justicia a esta Autoridad Diocesana en 25 de noviembre de 1851, 17 de febrero de 1852 y 20 de abril de 1853;43 esto no obstante, deseando ver establecida en dicho edificio una Comunidad religiosa que con su doctrina y buen ejemplo contribuya a moralizar las costumbres de los pueblos limitrofes al mismo, otorgo desde luego mi bendición y licencia, en cuanto a mí toca, a esas Misiones Franciscanas de Marruecos para que puedan establecer un Colegio en el referido Convento de Ntra. Sra. de Regla; como este pertenece a la Orden de Agustinos Calzados, deberá la de San Francisco entenderse en Roma, a fin de que todo se haga en debida forma canónica.

42 VALLECILLO MARTÍN, ob. cit., p. 875. Eiján fecha esta misiva el 18 de octubre.

43 Por la primera de estas disposiciones, se autoriza el traslado de la Virgen de Regla desde la parroquia al santuario; por la segunda, se nombran los capellanes procurando, en cuanto sea posible, que recaiga dicho nombramiento en exclaustrados que gocen sueldo del Estado; por la tercera, el estado se compromete a aportar para el culto del santuario un presupuesto anual de 4.446 reales, de los cuales 2.250 eran para materiales de culto y 2.196 para retribución de los dos capellanes exclaustrados. VALLECILLO MARTÍN, ob. cit., p. 876, n. 147. 
E1 24 de mayo de 1881, el P. Albiñana, vice-comisario apostólico de los franciscanos de España (1857-1884), nombró delegado suyo al P. Lerchundi, con plenas facultades, para el nuevo Colegio que se ha de establecer en Nuestra Sra. de Regla, cuya potestad comenzará desde el día de la inauguración... y durará por tiempo de un año solamente. ${ }^{44}$

Finalmente, la autorización pontificia vendría de la mano del nuncio en España, Angelo Bianchi (1879-1882), quien mediante oficio de 18 de enero de 1882 al P. Lerchundi, en uso de especiales facultades recibidas del Padre Santo, le adjuntaba un decreto suyo en el que daba su aprobación y consentimiento para la erección canónica del colegio de misioneros franciscanos en el ex convento de Regla; el decreto establecía, entre otras cosas, que en lo temporal, el colegio dependería de la Obra Pía de Jerusalén, institución que debía correr con todos los gastos de instalación, culto, sostenimiento y manutención de los religiosos, tal como venía haciendo con el colegio de Santiago. ${ }^{45}$

A la vista del anterior decreto de la nunciatura, el arzobispado hispalense concedió la aprobación canónica definitiva para la fundación del colegio en el santuario de Regla por los misioneros franciscanos, mediante un nuevo despacho fechado en Sevilla el 21 de febrero de 1882, en el que se decía que la mitra sevillana cedía a los franciscanos el citado edificio e iglesia y demás dependencias, bajo la precisa condición de que si alguna vez dejasen de servir para el expresado objeto, vuelvan inmediatamente a nuestra jurisdicción ordinaria. ${ }^{46}$

Varios días antes de este despacho, sin embargo, ya se habían dado los primeros pasos en el orden práctico para materializar la cesión; así, sabemos que el P. Lerchundi había recibido un oficio de la curia arzobispal sevillana participándole de que por un decreto anterior se habia ordenado al cura de Chipiona que pasando al Santuario de $N^{a} S^{a}$ de Regla, situado en su demarcación parroquial y puesto de acuerdo con el capellán, se procediese a la realización

\footnotetext{
44 EIJÁN, ob. cit., pp. 154-155.

45 Ibídem, p. 156.

46 VALLECILLO MARTÍN, ob. cit., p. 883.
} 
de dos inventarios: uno de todos los objetos, alhajas, ornamentos y demás que se hallasen en el santuario procedentes de los religiosos agustinos, a quienes pertenece dicho santuario, $y$ otro de todo cuanto con posterioridad a la exclaustración de los mismos haya sido donado por los devotos de la Stma. Virgen; una vez realizados así los dos inventarios, se ordenaba en dicho decreto el traslado a la parroquia de Chipiona de todos los objetos contenidos en el primero de dichos inventarios, los cuales conserva en la misma en clase de depósito hasta que otra cosa dispongamos. ${ }^{47}$

La toma de posesión del antiguo convento agustino tuvo lugar el 8 de marzo de 1882, y en ella estuvieron presentes el P. Lerchundi, don José Bustamante, capellán encargado del Santuario, y don Francisco Rubio Contreras, arcipreste de Sanlúcar de Barrameda: ${ }^{48}$

En el Santuario de Ntra. Sra. de Regla, dia 8 de marzo de 1882, en cumplimiento de lo dispuesto por S. E. I. el Arzobispo de Sevilla, y a presencia del Arcipreste de este partido de Sanlúcar de Barrameda, el capellán del referido Santuario ha hecho entrega al R. P. Fr. José Lerchundi, Prefecto Apostólico de las Misiones de Marruecos, del edificio del antiguo convento de Agustinos, iglesia del mismo con las alhajas de la Stma. Virgen, vestuarios, útiles y muebles que, particularmente y detalladamente, constan con toda distinción en los inventarios formados al efecto, y de los que se remite copia a la superior jurisdicción de Sevilla, quedando uno de sus originales en poder del referido $P$. Prefecto.

Con este acto se ponía fin a la llamada época de los capellanes del Santuario de Regla y comenzaba, si asi puede llamarse, la época de los franciscanos, que dura hasta nuestros dias. Sin embargo, esta transición parece que no se realizó bajo el signo de la cordialidad y de la paz: al efectuarse los inventarios mencionados, algo no se hizo correctamente y ello debió disgustar mucho al $P$. Lerchundi, que el 5 de marzo se quejó al arzobispo de la acción del párroco de Chipiona que se habia llevado algunas imágenes $y$ objetos del santuario. ${ }^{49}$ Así, el mismo día 8 de marzo, desde el arzobispado hispalense se oficiaba al P. Lerchundi haciéndole

\footnotetext{
Ibídem, p. 884 y n. 173.

EIJÁN, ob. cit., p. 158.

VALLECILLO MARTÍN, ob. cit., p. 884.
} 
saber el desagrado del arzobispo y la conminación que éste hacía al referido párroco de Chipiona. ${ }^{50}$

\section{LOS BENEDICTINOS FRANCESES DE SOLESMES Y LIGUGÉ}

Otra de las órdenes religiosas que estuvo interesada en el establecimiento en el santuario de Regla por estos mismos años fue la de los benedictinos, en concreto, los monjes franceses de los monasterios de San Pedro de Solesmes y San Martín de Ligugé, cuyos superiores habían comisionado a un religioso suyo, el $\mathrm{P}$. Ildefonso Guépin, ${ }^{51}$ para que buscase en España un lugar para estas dos comunidades, si finalmente se veían obligadas a abandonar su país: los benedictinos aparecian así en escena con la intención de quedarse, en principio sólo temporalmente, pero no lograron hacerlo en el santuario de Regla sino en el cenobio burgalés de Santo Domingo de Silos.

El 29 de marzo de 1880, el gobierno francés promulgó una serie de decretos que obligaron a las comunidades religiosas francesas a buscar refugios fuera de España, en donde poder vivir y perpetuar el ideal de la vida religiosa comunitaria. ${ }^{52}$ Ante esta tesitura, el abad

50 Ibídem. El oficio en cuestión decía: He recibido la apreciable carta de $V$. fecha 5 del corriente, y habiendo dado cuenta de ella a S.E.I. le ha desagradado mucho su contenido, y en su consecuencia, se dirige en este día al Cura de Chipiona el oficio que transcribo a $V$. en el adjunto que le acompaña, para que le sirva de satisfacción. (...). Con esta fecha dirijo al Cura Ecónomo de Chipiona el siguiente oficio: (...) En su consecuencia, habiendo llegado a noticia del expresado Excmo. Prelado que ha trasladado V. a esa su parroquia una imagen del Patriarca San José, que habia en la iglesia, y que se propone hacer lo mismo con otras imágenes u objetos de los queda hecha mención, me encarga dirija a V. el presente oficio, como de su orden lo verifico, para prevenirle devuelva dicha imagen a la iglesia del santuario y que se abstenga de hacer semejantes traslaciones (...).

51 El P. Ildefonso Guépin (1836-1917) profesó en el monasterio benedictino de Solesmes en 1860, siendo ordenado sacerdote cuatro años después; en 1880 llegó a España y contribuyó decisivamente a la restauración de la vida monástica en Santo Domingo de Silos, llegando a ser elegido su primer abad en 1894, cargo que ocuparia hasta su fallecimiento.

52 P. Lorenzo MATÉ SADORNIL, osb, "Correspondencia de Dom Guépin buscando en España un refugio para los monjes de Solesmes", en Glosas Silenses, año XXI, ${ }^{\circ}$ $1(2010)$ p. 27. Las cartas originales se escribieron en francés y han sido traducidas por este autor. 
del monasterio de Solesmes, dom Carlos Couturier, autorizó al P. Ildefonso Guépin para que viajase a España con el fin de encontrar algún monasterio abandonado allí que sirviese de morada para estos monjes hasta que la tormenta desatada pasase y se permitiera de nuevo el desarrollo de la vida religiosa por las autoridades francesas: ${ }^{53}$

El P. Guépin consultó al Nuncio [en Francia], monseñor Czasky, amigo y conocido suyo, quien le aconsejó buscar refugio en el extranjero para cuando llegara el momento de la expulsión. Como el P. Guépin pensaba en España, visitó en París a la reina Isabel II con el fin de conseguir alguna recomendación ante el rey de España, Alfonso XII, su hijo.

Con la finalidad arriba mencionada, el P. Guépin realizó dos viajes por España el año 1880: el primero, entre el 30 de mayo y el 8 de julio, y el segundo, del 15 de octubre al 19 de diciembre; durante estos viajes generó un volumen importante de correspondencia, parte de la cual se conserva hoy en el archivo del monasterio de Silos. A través de estas misivas, puede seguirse día a día el periplo del monje francés por tierras españolas, a la par que nos proporciona datos relevantes para el objeto de nuestro trabajo; por ello, en las líneas que siguen vamos a ir desgranando los detalles que nos aportan dichas cartas para arrojar luz sobre dicho objeto. ${ }^{54}$

En el primer viaje se dedicó fundamentalmente a realizar gestiones para encontrar un monasterio adecuado en España, en realidad dos, pues venía comisionado también por la abadía benedictina francesa de San Martín de Ligugé, para lo cual se entrevistó con muchas personas y visitó varios cenobios abandonados; en el segundo viaje, la finalidad era obtener la autorización de las autoridades españolas para que se pudieran establecer en el monasterio de Silos los monjes de la abadía de San Martín, por lo que básicamente transcurrió en Madrid, con alguna que otra visita a monasterios cercanos a la capital de España. ${ }^{55}$

53 Ídem, p. 29. La carta se conserva en el archivo del monasterio de Silos, pues dom Guépin, siguiendo el consejo del nuncio en España, como veremos, no hizo uso de ella (n. 3).

${ }^{54}$ Como sólo se conservan las misivas enviadas por el monje francés a su superior y no las respuestas de éste, es evidente que existe una cierta laguna, pero nada relevante para lo que aquí se trata.

55 Cfr. MATÉ SADORNIL, ob. cit., pp. 29-30. 
El 30 de mayo de 1880, desde Miranda de Ebro, dirige el P. Guépin a su superior una primera misiva en la que manifiesta su contento diciendo: Ya era hora de venir a España; todos los religiosos franceses acuden aqui: los dominicos de San Máximo se establecen en Salamanca; los Padres de la Misión de África, en Bugedo, abadía premostratense, a tres leguas de Miranda; los redentoristas, en nuestra abadía del Espino, etc. ${ }^{56}$

Unos dias después, el 6 de junio, escribe de nuevo a su superior para hacerle la siguiente confidencia: pienso que es inútil buscar algo más al sur de Madrid. Está muy lejos de Francia; y sólo el clima nos causaría muchos inconvenientes. ${ }^{57}$

Al día siguiente, parte para Madrid, donde el día 8 visita al nuncio en España, monseñor Bianchi, a quien expuso el motivo de su viaje y le mostró su carta credencial; la respuesta del nuncio, resumida por el monje benedictino, no pudo ser más explícita: ${ }^{58}$

Haré por Uds. todo lo que pueda, pero, por ahora, tengo tantos asuntos de este género entre manos, que no puedo tomar uno más, so pena de parecer inoportuno y de complicarlo todo. Todos los religiosos entran a la vez en España; el primer ministro [Cánovas] está muy bien dispuesto, pero tiene que contar con la oposición y con sus oficinas, que están llenas de masones y republicanos. Este pobre país está en un estado lamentable, no hay orden ni politica, lo cual tiene al menos esta ventaja: basta con entrar para quedarse aquí; una vez que se está en él, se os deja, sobre todo a Uds., emigrados y que no buscan hacer un establecimiento definitivo en suelo español, tienen todas las ventajas para ser bien recibidos. (...); y una vez que hayan entrado sin ruido, se quedarán. (...). Ud. no tiene tiempo que perder aqui; estamos ya a 8 y el 29 es el vencimiento de los decretos, por tanto, deben darse prisa.

56 MATÉ SADORNIL, ob. cit., p. 33.

57 Ibídem, p. 54.

58 Ídem, pp. 57-58. También le preguntó al nuncio si las recomendaciones ante el rey y la reina podian serle útiles, quien le contestó que eso jamás puede hacer mal, pero no sé para qué puede serviros; la única persona que podría seros útil está ausente, es la princesa de Asturias; consejo que el P. Guépin siguió y por eso no mostró la carta a que hemos aludido en nota anterior. 
En nueva carta, fechada desde Valladolid el 10 de junio, el P. Guépin expone el plan a seguir en su viaje: ${ }^{59}$

No debemos pedir ningún otro favor al Gobierno de este pais, sino que cierre los ojos en el momento de nuestra llegada, si es que tiene lugar. Hay que entenderse con los obispos y pedirles el albergue que el Gobierno no osaria darnos. (...); tenemos ya Cardeña; esta noche salgo para Oviedo, donde veré al Obispo para preguntarle si quiere poner Cornellana a nuestra disposición, (...). De Oviedo iré por tierra a Compostela; alli veré al Cardenal para saber si nos da San Martin; y si San Martín nos conviene, no tenderemos más apuros que la elección. Con los señores Fabre poniendo sus barcos a nuestra disposición, el traslado de las comunidades a Cornellana y Compostela sería muy poco costoso.

El 13 de junio ya había visitado el monasterio de Cornellana y había sido recibido por el vicario general de la diócesis asturiana, en ausencia del prelado; al parecer, el monasterio se encontraba en un estado bastante aceptable, que podía ser reparado con pocos costes para ello, por lo que el P. Guépin quedó en que al día siguiente hablaria con el vicario de Oviedo para pedirle condicionalmente la preferencia para Cornellana. ${ }^{60}$

E1 16 de junio se encuentra en León, desde donde se encaminó, al día siguiente, a Grajal, villa cercana a Sahagún, para entrevistarse con el prelado diocesano, don Saturnino Fernández de Castro, ${ }^{61}$ quien se encontraba allí en visita pastoral; el obispo recibió al P. Guépin por la tarde y le dijo haber recibido una circular del gobierno español declarándose dispuesto a permitir la entrada en España de los religiosos franceses con dos condiciones: primera, que no se quedarán en las provincias limitrofes con Francia; segunda

MATÉ SADORNIL, ob. cit., p. 62.

60 Ídem, p. 68.

61 El Dr. D. Saturnino Fernández de Castro (1827-1886) fue obispo de León desde 1875 hasta 1883, en que fue preconizado para la sede burgalesa; de él dice el P. Guépin: El ilustrísimo señor doctor don Saturnino Fernández de Castro, obispo de León, conde de Colle, señor de los lugares de las Arrimadas y Vegamián, etc., etc., es un prelado de una dignidad grave y distinguida por su misma sencillez. Tiene el pelo blanco, está muy delgado, y quienes le rodean quieren encontrarle algún parecido con León XIII (MATÉ SADORNIL, "Correspondencia de Dom Guépin buscando en España un refugio para los monjes de Solesmes 1880-1881 (continuación)", en Glosas Silenses, año XXI, n 2 (2010) p. 160. 
que los obispos pedirán al gobierno la autorización para ellos. ${ }^{62}$ Con el obispo también habló acerca de la posible instalación de los monjes franceses en Santo Toribio de Liébana, a lo que el prelado se mostró receptivo, quedando el asunto pendiente de la visita del monje francés a este cenobio.

Después de esta visita, el P. Guépin escribió de nuevo a su abad desdiciéndose de su anterior opinión, recogida más arriba, pues dejaba caer que quizá haya que buscar en Valencia, Murcia y más al sur de Madrid, aún reconociendo que eran lugares muy alejados de Francia y el clima aplanador de esos lugares es temible. ${ }^{63}$

El 19 de junio llegó al monasterio de Silos, en Burgos, sobre el que remitió un extenso y detallado informe a su abad en carta del día siguiente, enterado ya de que a los trapenses franceses se les había concedido el monasterio de Cardeña, situado en la misma diócesis; en carta de 25 de junio a su abad le informaba de que salía inmediatamente para Liébana y probablemente para Galicia, al mismo tiempo que se desahogaba diciéndole: hemos perdido Cardeña, quizá por mi culpa, pero en su lugar tenemos Santo Domingo de Silos, que vale más aunque esté en peor estado, palabras que resultarian premonitorias de lo que ocurriria finalmente. ${ }^{64}$

Por una carta fechada el 25 de junio y dirigida a su abad desde Venta de Baños nos enteramos de la existencia de otra misiva destinada al cardenal Pitra (1812-1889), protector de los benedictinos franceses y buen conocedor de la curia romana, para que éste obtuviese del Santo Padre el favor demandado; a lo que parece, el favor consistiria en que el papa escribiese al gobierno de España recomendando a los benedictinos de Solesmes para que

62 MATÉ SADORNIL, ob. cit., p. 160, quien puntualiza que la Real Orden de 1 de julio de 1880 , a que se debió referir el obispo leonés en su conversación, prohibía efectivamente el establecimiento de los religiosos franceses en las provincias limítrofes, pero, en cuanto a las autorizaciones se ordenaba que serian dadas por el gobierno, sin incluir ninguna alusión a los obispos; finalmente, la disposición mencionada establecía que el gobierno recabaria los informes oportunos a tal efecto, por eso quizá el Obispo quiso decir que daría informes favorables.

63 En carta fechada el 17 de junio de 1880 desde Grajal; cfr. MATÉ SADORNIL, ob. cit., p. 162.

${ }^{64}$ Cfr. MATÉ SADORNIL, ob. cit., p. 170. 
fueran recibidos en España, siguiendo así el consejo que en su día recibió Guépin del nuncio en España en la entrevista que ambos mantuvieron el 8 de junio anterior, según ya hemos visto. ${ }^{65}$

Tres dias después, desde Potes, remitía un extenso informe acerca del estado del monasterio de Santo Toribio de Liébana tras la pertinente visita; el lugar le pareció un paraiso terrenal pero con el inconveniente serio de su situación geográfica y su reducido tamaño; y finalizaba su misiva diciendo: ${ }^{66}$

Tengo informes de casi todos los monasterios indicados en la lista guia redactada por Dom Plaine. De todos ellos sólo hay uno posible, Silos; Oña debe ser vendido estos dias a los jesuitas. Con Oña y Silos estariamos muy bien provistos. Confio en que Dios no nos abandone y en que no vuelva a Francia sin haber encontrado un segundo albergue que supla las imperfecciones del primero.

E1 30 de junio de 1880, el P. Guépin llegó a la ciudad de Santander, enfermo, según el mismo reconoce, y se alojó en el hotel "Europa", regentado por un compatriota suyo; al dia siguiente fue presentado al obispo de la diócesis, don Vicente Calvo y Valero, ${ }^{67}$ quien le comunicó que no tenía ningún monasterio que ofrecerle aunque, eso sí, le invitó a hospedarse en el obispado; el 2 de julio, el obispo pasó la mañana con el monje francés, invitándolo a concelebrar la eucaristía en su capilla privada y enseñándole después el seminario diocesano; fue entonces cuando le dijo lo que sigue: ${ }^{68}$

Me viene una idea, me dijo. Hay en Andalucia, en Como [sic], ${ }^{69}$ a legua y media de Sanlúcar de Barrameda, ciudad rica y piadosa, y a un cuarto de hora de Chipiona, en la diócesis de Sevilla, un gran monasterio de agustinos, bajo el título de Nuestra Señora de Regla. Está situado en

65 Ídem, p. 171 y n. 11.

66 Ídem, p. 180; cfr. Ibídem, pp. 172-180.

67 Don Vicente Calvo y Valero (1838-1898), natural de Sevilla, fue promovido al obispado de Santander en 1876, sede que ocupó hasta 1884, en que pasó a la sede gaditana, donde permaneceria hasta su fallecimiento; de él dice Guépin en su carta que era un andaluz de aspecto bondadoso y casi infantil. MATÉ SADORNIL, ob. cit., p. 180.

68 En carta de dom Guépin a su abad, del día 1 de julio. MATÉ SADORNIL, ob. cit., pp. 181-185.

69 Así en el original, pero por el contexto, se deduce que se trata de Chipiona. 
la orilla del mar, en una campiña deliciosa. Muchas familias de Sevilla pasan el verano en este lugar, porque la brisa del mar templa el calor ambiental. Yo mismo he pasado alli dos o tres temporadas. La iglesia no es muy grande, pero está en buen estado. Es un poco menos larga pero más ancha que la del seminario [de Santander] (seria suficiente; las iglesias monásticas raramente son grandes en España). El monasterio tiene dos claustros; el primero, que servía de hospedería, está, al menos en parte, en bastante mal estado; el segundo está bien conservado; las habitaciones son pequeñas, pero me parece que alli podrian alojarse bien 60 monjes. La devoción a la imagen de la Santísima Virgen es muy grande, y Andalucía es la región de España donde se encargan más misas y a un precio más alto. (...). Santo Tomás de Villanueva vivió en Como y aún se conserva su celda.

Monseñor Calvo le dijo también que el monasterio pertenecía al arzobispado hispalense y que, precisamente por aquellos días, monseñor Lluch, titular de la sede hispalense, iría a tomar las aguas a Alhama de Aragón, entre Sigüenza y Zaragoza, donde podría encontrarle, añadiendo, en tono confidencial, que si Vd. pudiera conseguir una recomendación de algún personaje grande de la Corte para el Señor Arzobispo, le aseguro que le concederá cuanto le pida, a lo que el monje francés contestó si las cartas que llevaba del cardenal Pitra harian buen efecto, respondiéndole el prelado que sí, ciertamente, pero las otras muchísimo más, y esto se lo digo con toda reserva $;^{70}$ en esta misma carta, el P. Guépin informaba a su superior de que los señores Fabre deben tener corresponsales en Cádiz, por ellos se podria saber exactamente el estado del monasterio de Como [sic, Regla]. ${ }^{71}$

El P. Guépin, según Vallecillo, escribió el 4 de julio de 1880 al nuncio en España para que le recomendase al arzobispo de Sevilla y apoyase la solicitud de entrega del santuario de Regla a los benedictinos franceses: ${ }^{72}$

70 MATÉ SADORNIL, ob. cit., p. 184.

71 Ídem, pp. 184-185.

72 VALLECILLO MARTÍN, ob. cit., p. 873 y n. 137. La que traducida dice, más o menos, lo que sigue: He viajado mucho e inútilmente para encontrar un segundo monasterio, necesario para nuestras dos comunidades de Solesmes y Ligugé. Siguiendo las indicaciones recibidas del obispo de Santander, tengo intención de solicitar al arzobispo de Sevilla el antiguo convento de los agustinos de Ntra. Sra. de Regla, cerca de Sanlúcar de Barrameda. A nosotros nos vendría de maravilla, a pesar de su lejanía de Francia. 
J'ai beaucoup voyagé et inutilement pour trouver le second monastère nécessaire ê nos deux communautés de Solesmes et de Ligugé. D'après les indications que m'a données Monseigneur l'Evêque de Santander, j'ai l'intention de demander à Monseigneur l'Archevêque de Seville l'ancien couvent des Augustines de Nuestra Señora de Regla, près de Sanlúcar de Barrameda. A nous conviendrait à merveille, malgré son éloignement de la France.

El 5 de julio, todavía en Santander, coincide el P. Guépin con el Patriarca de las Indias, el cardenal Benavides, ${ }^{73}$ con quien estuvo en compañía del obispo Calvo, y de quien consiguió una carta de recomendación para el presidente del gobierno español, que no será de gran peso, pero siempre será algo. ${ }^{74}$

Por fin, el 8 de julio se encontraba nuestro monje viajero en Alhama, el último punto antes de abandonar Francia para regresar a su pais; durante el viaje, la Providencia me ha hecho encontrar en el camino a un canónigo de Zaragoza, antiguo secretario del Arzobispo de Sevilla, quien le sirvió de guía, y gracias a sus buenos oficios, pudo ver al prelado hispalense aquella misma mañana, de quien dejó escrito: ${ }^{75}$

Fray Joaquín Lluch, catalán de origen y carmelita calzado por profesión, fue echado de su convento inmediatamente después de su profesión. Vivió en Francia, en Carcasona, después en Luca y en Roma, donde continuó sus estudios y la carrera dentro de su Orden. Habla francés con facilidad y perfectamente bien el italiano. Sucesivamente, ha sido obispo de Canarias, Salamanca y Barcelona, y se dice ahora que desearia llegar a cardenal. Por esta razón se me había dicho que la carta del cardenal Pitra tendría un efecto maravilloso. El prelado es un hombre enorme (...); tiene mirada penetrante y un poco toda la dignidad de un italiano con un falso aire de cura de Aquabella; sólo que en lugar de encontrar bajo la aterciopelada y cariñosa mirada un fondo insondable como en don Gabriel, uno se pregunta si, perforando la corteza, no se encontraría otra cosa... mucho cálculo, mucha política, pero ¿qué importa?

73 Don Francisco de Paula Benavides Navarrete (1810-1895), natural de Baeza, obispo de Sigüenza desde 1857, fue promovido a la dignidad de Patriarca de las Indias en 1875 y dos años después creado cardenal por Pío IX.

74 MATE SADORNIL, ob. cit., p. 185.

75 Ídem, pp. 186- 187. 
En la entrevista mantenida con monseñor Lluch, de apenas media hora, el prelado le manifestó al P. Guépin su amor por todas las órdenes religiosas, muchas de las cuales habia ya restablecido en la archidiócesis hispalense, entre otras, los carmelitas descalzos en Jerez de la Frontera, pero no son más que cuatro viejos, parece que le dijo; también le habló de las Hermanitas de los Pobres, que habian comprado la antigua abadía benedictina de Sevilla, junto a la puerta de Carmona, por la que un tiempo antes se habia interesado también un joven prior belga, el P. Gerardo von Caloën, dispuesto asimismo a adquirirla; finalmente, le ofreció la posibilidad de comprar un gran convento de agustinos que servía de presidio, función que había dejado de prestar el edificio, por lo que sería puesto en venta por el gobierno; ya casi al final de la entrevista, pudo derivar la conversación hacia el santuario de Regla: ${ }^{76}$

... después de una larga espera, pude meter una palabra sobre Regla. "Por mi parte no encontraréis ninguna dificultad en la realización de tal proyecto; los arzobispos iban en ocasiones a pasar algún tiempo en Regla; yo tengo buenos aposentos y buenos conocidos en Sanlúcar de Barrameda, pero nunca he estado en Regla, salvo algunas horas; pero sería necesario el consentimiento del duque de Montpensier, que va allá alguna vez con su familian. Respondí que yo conseguiría el consentimiento del duque. "Pero", me dijo el arzobispo, "ustedes no podrán alojar 80 monjes en Regla". Respondi que no era nuestra intención y que si pudiéramos alojar alli 30 o 40 nos bastaría. El arzobispo me dijo creía que no había sitio más que para una docena de monjes. Por lo demás no conoce Regla más que grosso modo. Me confirmó lo que me habian dicho en Santander sobre la abundancia de misas y limosnas y la piedad de los fieles hacia la santa imagen. Se ve que vive en una región muy distinta de la de los otros obispos españoles y que tiene entre manos recursos que a los otros les faltan.

Finalizada la reseña de la entrevista, el P. Guépin dijo en esta misma carta a su abad que tenía intención de escribir inmediatamente al obispo de Santander, monseñor Calvo Valero, rogándole pida informes precisos sobre Regla, ya que sus noticias sobre el santuario eran diferentes de lo que le había manifestado

76 Ídem, p.188. 
el arzobispo Lluch en el encuentro mantenido con él; así, continúa diciendo en la carta a su abad: el convento es más grande de lo que imagina el arzobispo; tiene dos claustros, y dos claustros en España suponen al menos 30 religiosos. El duque de Montpensier está en Francia. Si usted toma este proyecto en serio, no convendrá dejarle volver a España sin tener antes su consentimiento; él ha restaurado Regla y es casi el propietario. ${ }^{77}$

Pocos días después de esta carta, el P. Guépin ponía punto final al primer viaje y regresaba al monasterio de Solesmes para reencontrarse con su abad.

En relación con este asunto, por el P. Vallecillo sabemos que el 27 de mayo el arzobispo Lluch había escrito una carta al nuncio en España en la que le solicitaba ofreciese sus buenos oficios ante el Ministerio de Gracia y Justicia para que no pusiese obstáculos en el nombramiento del canónigo don Marcelo Spínola como obispo auxiliar de la archidiócesis sevillana; el nuncio, como para cobrar el favor, nos sigue diciendo Vallecillo, escribió al arzobispo de Sevilla el 7 de julio intercediendo para que les concediese a los benedictinos franceses, recomendados a su persona por el cardenal Pitra, el convento de Regla al mismo tiempo que le comunicaba que el asunto del obispo auxiliar iba por buen camino; el arzobispo hispalense contestó al nuncio al día siguiente, esto es, el mismo día de la entrevista con Guépin, informándole sobre cómo se había desarrollado ésta y diciéndole al nuncio que le habia dado todas las facilidades [al P. Guépin] para que realizasen su propósito, por lo que inmediatamente habia vuelto a Solesmes a informar a sus superiores. ${ }^{78}$

Una vez en Francia, el P. Guépin, por carta dirigida al abad de Ligugé desde Quintín el 19 de septiembre, le informa de que el duque de Montpensier ha escrito una carta encantadora sobre Regla y vamos a tener por medio de los señores Fabre informes $y$ hasta un plano de esta casa; mi opinión es que convendría enviar ya alguna persona a España; y en otra misiva, de la misma fecha pero dirigida

77 Ibídem.

78 VALLECILLO MARTÍN, ob. cit., pp. 873-874. 
al abad de Solesmes, apostilla: ¿Ha recibido el P. Fabre los informes sobre Regla? Me alegra que este asunto quede concluido. ${ }^{79}$

De nuevo en España, el P. Guépin retoma la comunicación epistolar con su superior, a quien escribe el 4 de noviembre desde Madrid: 80

Esta mañana he visto al obispo auxiliar de Madrid, presidente de la junta creada para ayudar a los religiosos franceses. (...). Después he visto al nuncio, que me ha dicho: "tienen que saber necesariamente qué quieren y decidirse. Acepten lo que les ofrecen y cuando estén aquí, haré lo posible para ayudarles". He sabido por el cardenal Moreno que el arzobispo de Sevilla le habia hablado de nuestra llegada a Regla. El duque de Montpensier habia tenido, antes de recibir sus cartas, el deseo de poner alli a los capuchinos españoles expulsados de Perpiñán; el arzobispo ha rehusado diciendo que nosotros teniamos su palabra; el duque entonces colocó a los capuchinos en Sanlúcar de Barrameda.

En esta misma carta se despide de su abad diciéndole que le alegraría mucho tener noticias suyas y sobre todo sus órdenes, especialmente en lo relativo a las siguientes cuestiones: si convenía presentar una solicitud para nuestro establecimiento en Regla; si habia que buscar un tercer monasterio, cuántos y qué monjes se alojarian en él y si aceptaba la idea de un establecimiento provisional de los estudiantes en Salamanca. ${ }^{81}$ Terminaba la misiva diciéndole al abad que cuando tuviese respuesta a estas cuestiones podría caminar con seguridad, con la ayuda de Dios, y tener éxito, según espero.

El 9 de noviembre, desde Madrid informa a su abad en nueva carta de que aún no había hecho nada por Regla, porque esperaba conocer definitivamente vuestras instrucciones. ${ }^{82} \mathrm{Y}$ dos dias después

79 MATÉ SADORNIL, ob. cit., pp. 190 y 192.

80 Ídem, p. 200 y n. 38. Al parecer, en el Archivo de Silos se conserva una carta de dom Couturier, de fecha 6 de septiembre, acusando recibo de las cartas del duque de Montpensier en las que le dice que el monasterio de Regla pertenece al arzobispado hispalense aunque el duque lo haya reparado.

81 MATÉ SADORNIL, ob. cit., pp. 201-202.

82 MATÉ SADORNIL, "Correspondencia de Dom Guépin buscando en España un refugio para los monjes de Solesmes, 1880-1881 (conclusión)", en Glosas Silenses (2010) año XXI, nº 3, p. 269. 
recibe la noticia sobre el desenlace del asunto de Regla: Un franciscano, que llega de Andalucia, ${ }^{83}$ me ha dicho que Regla acaba de ser dado a los franciscanos de Marruecos; esto lo sabe el mismo arzobispo de Sevilla. Escribo al prelado para saber si todo esto es cierto. $^{84}$

La carta dirigida al prelado sevillano lleva fecha de 9 de noviembre, la respuesta de éste, en otra carta, se produce el día 12, y sobre la misma escribe a su abad, el día 16, diciéndole: he recibido a mi regreso una carta muy afectuosa del arzobispo de Sevilla, que me dice, en efecto, que los franciscanos de Marruecos han obtenido, a espaldas suyas, Regla; nos ofrece a cambio su casa de campo, invitándome a ir a verla. ¿Le parece aceptable? ${ }^{35}$ Esta casa de campo no era otra que el palacio que la mitra sevillana poseía en la localidad de Umbrete.

El 15 de noviembre le escribe al P. Guépin el prior de su monasterio, por indicación del abad, en contestación de su anterior del día 9 de ese mes, transmitiéndole las instrucciones solicitadas:

He aquí en resumen a qué se atendrá. Además de Santo Domingo de Silos, del cual ya estáis seguro, convendría intentar asegurar Liébana. El reverendísimo P. Abad no cree prudente, visto el estado de España, hacer en ese pais establecimientos considerables. Dignese actuar en este sentido y arreglar todo lo mejor posible; por ahora le es imposible determinar a quiénes enviará a España, pero, en cualquier caso, estos dos monasterios le bastan y no quiere otros.

83 Es posible que se trate del franciscano P. Juan Maria de Quillán y Ormieres, franciscano francés, a quien menciona en otra carta posterior diciendo que está aqui [en el Ministerio] conmigo y que solicita el convento de Loreto, cerca de Sevilla; cfr. MATÉ SADORNIL, ob. cit., p. 296, carta de 11 de diciembre de 1880. E1 P. Quillán pertenecía a la disuelta comunidad franciscana francesa de Bourges y finalmente consiguió la autorización ministerial el 20 de diciembre de 1880 para que su comunidad se instalase en el santuario de Loreto, lo que aconteció al año siguiente; cfr. AMORES MARTÍNEZ, Francisco, "El convento sevillano de Nuestra Señora de Loreto. Historia, arte y espiritualidad”, en VV. AA., I Simposium Cuatro siglos de presencia de los franciscanos en Estepa, Estepa, 2007, pp. 129-130.

84 Carta a su abad desde Madrid el 11 de noviembre. Ídem, p. 270.

85 Ídem, p. 272 y n. 8. 
Las instrucciones recibidas eran muy claras y a ellas se atendrá el P. Guépin en adelante, aunque no deje de referirse en sus cartas al ofrecimiento realizado por el prelado sevillano, como en la carta que remitió el 2 diciembre a su abad: el arzobispo de Sevilla nos ofrece, a Solesmes, su palacio de Umbrete en lugar de Regla (...). Seguro que no se le responderá, ni siquiera para darle las gracias. ${ }^{86}$

El día 7 de diciembre los benedictinos de Solesmes consiguieron autorización del gobierno español para instalarse en el monasterio de Santo Domingo de Silos. ${ }^{87}$ Aún así, el P. Guépin seguía sondeando otras posibilidades, pero descartando ya el ofrecimiento de Umbrete, como se desprende de la carta de 9 de diciembre, en la que el P. Guépin dice a su abad que el arzobispo de Sevilla nos ofrece su palacio de Umbrete, me parece que no es apto para nosotros y añade a renglón seguido: ${ }^{88}$

Los franciscanos de Marruecos tomaron Regla, pero obtendríamos sin dificultad la antigua cartuja de Jerez. Andalucia es la región más rica de España. Sus habitantes son muy generosos. Es el único lugar de España donde encontrariamos fácilmente recursos. Podríamos obtener también la antigua universidad de Osuna, situada en una ciudad de 12.000 habitantes. He escrito para tener informes.

Y en otra de 14 de diciembre de 1880 sentencia acerca del palacio episcopal de Umbrete: no es una abadía sino una casa de campo lo que el arzobispo de Sevilla nos ofrece en lugar de Regla, ocupado por los franciscanos de Marruecos. ${ }^{89}$

El 19 de diciembre, finalmente, se restauraba la vida monástica en Silos por los benedictinos franceses de Solesmes.

Muchos años después de estos acontecimientos, convertido el P. Guépin en el primer abad de Silos tras su restauración, dirá en sus memorias lo siguiente respecto a los mismos: ${ }^{90}$

86 Ídem, p. 280.

87 Ídem, p. 282.

88 Ídem, p. 288.

89 Ídem, p. 300.

90 MATÉ SADORNIL, P. Lorenzo, osb, "Memorias de Dom Guépin sobre la restauración de Silos (fin)", en Glosas Silenses, (2008) n 3, p. 260. 
El obispo de Santander [Calvo Valero], andaluz, insistió mucho recomendándome el convento de Regla, que el duque de Montpensier habia salvado de la ruina y habitado con su familia durante muchos veranos. Fui hasta el balneario de Alhama de Aragón para ver al cardenal Lluch, carmelita y arzobispo de Sevilla, que me recibió maravillosamente. A petición de su hermano Cipriano [monje de Solesmes], el Sr. Fabre, de Marsella, hizo llegar a Solesmes un plano del convento de Regla, realizado gracias a la solicitud de su agente en Chipiona, donde tenia relaciones comerciales. Este monasterio no podía convenirnos y los franciscanos de Marruecos no han tardado en ocuparlo.

\section{OTRAS ÓRDENES RELIGIOSAS INTERESADAS EN EL SANTUARIO}

Hemos visto en las páginas que anteceden, aunque de pasada, cómo existieron otras órdenes religiosas interesadas por el santuario de Regla con vistas a instalar a sus religiosos en este cenobio.

El P. Castellanos es el primero en proporcionarnos algunos detalles acerca de otros religiosos que se interesaron por el Santuario de Regla, si bien no especifica la fecha en que se manifestó ese interés: ${ }^{91}$

Por otra parte, los muros del edificio íbanse cuarteando, las bóvedas venianse a tierra y la casa de la Madre de nuestro Dios, amenazaba ruina, (...). Tan ruinoso estaba todo el Santuario, que, deseando los Padres Agustinos destinados a las Misiones de Filipinas, fundar en él un Colegio, abandonaron su proyecto no bien se hicieron cargo del estado en que se hallaba.

En primer lugar, habría que señalar que llama mucho la atención la descripción que hace el P. Castellanos acerca del estado del Santuario pues parece no coincidir con la que realiza el P. Lerchundi, quien, como ya hemos visto más arriba, hablaba en su informe de que el Santuario se conserva en el mejor estado posible, excepto una pequeña parte que quedó por restaurar. Por otro lado, la referencia a los padres agustinos destinados a las misiones de Filipinas podría entenderse realizada tanto a los agustinos ermitaños como a los recoletos, pues, como ya vimos, ambos tenían colegios destinados a las misiones de Filipinas; vamos pues a intentar aclarar algo sobre este punto.

91 CASTELlANOS, ob. cit., pp. 62-63. 
Lo primero que hay que decir es que, con fecha 2 de junio de 1858, el comisario de los agustinos recoletos de la provincia de Filipinas en España, P. Guillermo Agudo, remitió un oficio al provincial de dicha provincia para... ${ }^{92}$

...participarle que el Gobierno español tenía gran empeño en que los Agustinos Calzados y Recoletos se hicieran cargo del antiguo convento de la orden bajo la advocación de Nuestra Señora de Regla, en Chipiona, provincia de Cádiz, y del de La Rábida, en la de Huelva, situados ambos en despoblado, y que habian sido restaurados por los duques de Montpensier, para que los religiosos los conservaran.

A renglón seguido, añadía en su oficio el P. Agudo que había contestado negativamente a este ofrecimiento del gobierno manifestándole que no nos convenían por no ser útiles para nuestro fin actual, ni contaba la Provincia con personal necesario, ni los debidos intereses para su conservación; ${ }^{93}$ de donde se deduce que, al menos a los agustinos recoletos, en esta fecha, no les interesó el Santuario de Regla, por los motivos aducidos, entre los cuales no aparece el supuesto estado ruinoso del edificio de que habla el P. Castellanos.

Más adelante, en otro oficio, fechado en Madrid el 3 de octubre de 1864 , y dirigido igualmente al provincial y su definitorio, les dice el P. Agudo, con ocasión de las dificultades previstas para hallar local a propósito para instalar la nueva casa o colegio que desea nuestra Provincia, lo que sigue: ${ }^{94}$

Espero que Vuestras Reverencias no se alucinen con las noticias que puedan llegarles de que (...) al Padre Celestino Mayor le darán el convento de Regla también de balde; mas sólo es casa para veinticinco frailes, y si lo han de aumentar, como es de necesidad si ha de llenar el objeto a que se destina, al último se sabrá lo que les cuesta, amén de la huerta.

92 CARCELLER, Fr. Manuel, oar, Historia General de la Orden de Agustinos Recoletos, Madrid, 1967, t. XI, p. 419. Ejemplar consultado en línea en el sitio Biblioteca Electrónica Agustino Recoleta.

93 Ibídem.

94 Ídem, p. 716. El P. Celestino Mayor era entonces el comisario de los agustinos calzados o ermitaños en España. 
De donde quizás podamos deducir que hubo un posterior ofrecimiento del santuario de Regla a los agustinos ermitaños, acerca del cual no tenemos más noticia, pero, en todo caso, parece que sea la pequeñez del lugar más que su estado de conservación lo que hacía que fuese desestimado por los agustinos para fundación del colegio.

Por otro lado, el P. Lerchundi decía, en carta dirigida a la Obra Pía el 24 de agosto de 1880, reproducida más arriba, que en su visita al santuario de Regla, el capellán le aseguró que los PP. Jesuitas procedentes de Francia desean apoderarse del convento y que al efecto, hace unos ocho dias mandaron comisionados para que se enteraran del estado en que se encontraba el edificio. ${ }^{95} \mathrm{En}$ este caso, creemos que debió tratarse de una confusión, bien del propio franciscano o bien del capellán del santuario, con los benedictinos franceses quienes, como hemos visto más arriba, sí que habían comisionado a cierta persona para el citado objeto: el agente en Chipiona de la compañia mercantil de los hermanos Fabre, de Marsella, vinculados familiarmente con los benedictinos franceses $\mathrm{y}$ con relaciones mercantiles en la costa gaditana; a la misma conclusión parece llegar el P. Vallecillo en su trabajo tantas veces citado: viendo todo esto con la perspectiva que nos proporcionan los documentos consultados, podemos decir que eran los Benedictinos de Solesmes, y no los jesuitas, los que se interponian peligrosamente en el camino del P. Lerchundi. ${ }^{96}$

También, en una de sus cartas, fechada en Madrid el 4 de noviembre de 1880 , tal como ya hemos visto, el P. Guépin se refería al interés del duque de Montpensier por instalar en el Santuario de Regla una comunidad de capuchinos españoles expulsados de Perpiñán, pero como el arzobispo sevillano había rechazado esta fundación, por haber dado su palabra a los benedictinos franceses de Solesmes, el duque entonces colocó a los capuchinos en Sanlúcar de Barrameda; es posible que el benedictino francés, generalmente bien informado, no lo estuviera en este caso pues es sabido que en 1877 el capuchino fray Esteban de Adoáin restauró el convento de

95 VALLECILLO MARTÍN, ob. cit., p. 867-8 y n. 123.

96 VALLECILLO MARTÍN, ob. cit., pp. 874-875. 
su orden en Sanlúcar de Barrameda, siendo su primer guardián; ${ }^{97}$ aunque cabe la posibilidad de que el P. Guépin se estuviera refiriendo a otro caso, del tenor de sus palabras no puede deducirse cosa distinta.

Finalmente, en el trabajo ya citado del franciscano Eiján, se habla de otra institución religiosa interesada en instalarse en el santuario de Regla, basándose para ello en la hipótesis de que el compromiso del arzobispo sevillano para no entregar el santuario a los franciscanos no debia ser con los PP. Jesuitas o Agustinos de que hizo mención el capellán de Regla al P. Lerchundi, sino con el cardenal Lavigerie, fundador de los misioneros de África (Padres Blancos), y sus manejos para crear un Vicariato Apostólico de Marruecos con colegios en España destinados a la educación cristiana de negros niños y niñas-que alli se recogiesen; para establecer esta hipótesis se basa Eiján en que el P. Adolfo Papotard, Vicario General de las Misiones Africanas, había solicitado autorización al gobierno español para fundar en la Península, adelantándose ya a pedir el edificio de Regla para instalar uno de dichos Colegios, pero el gobierno, antes de tomar una decisión, habia solicitado informe sobre el particular al Comisario de Tierra Santa, quien a su vez, o mejor, quien entonces hacía sus veces, D. Vicente Martín, lo había pedido al $\mathrm{P}$. Lerchundi, que en misiva fechada en Tánger el 10 de septiembre de 1880 , destacaba los aspectos negativos de este propósito para los intereses españoles en África. ${ }^{98}$

En opinión de Eiján, el gobierno español, a la vista de dicho informe, debió desestimar la petición de fundar en España el $P$. Papotard, anulando asi el compromiso del Sr. Arzobispo y quedando,

97 El P. Esteban (1808-1880) llegó a Francia en marzo de 1873, procedente de Guatemala, de donde había sido desterrado, con un grupo de otros religiosos, incorporándose al convento de Bayona, que se componía de capuchinos españoles y allí permaneció hasta 1877, en que fue destinado primero a Antequera, para restaurar el convento capuchino, y poco después, a finales de junio de ese mismo año, a Sanlúcar de Barrameda con el mismo fin, donde le sorprendió la muerte en mayo de 1880. Los datos en http:/ / www.capuchinoseditorial.org/, consultado en línea el 07-08-2014, y en MARTÍN RIEGO, “Exclaustración y..., ob. cit., p. 225.

98 EIJÁN, ob. cit., pp. 152-153, quien reproduce integramente el informe dado por el P. Lerchundi, y con él también, VALLECILLO MARTÍN, ob. cit., pp. 868-870 y n. 125 . 
por tanto, en libertad de acción el Arzobispo para obrar libremente, resultando asi indudable que a esto haya obedecido su cambio de actitud respecto a la entrega del Santuario de Regla. ${ }^{99}$ Creemos nosotros, en cambio, que esta hipótesis establecida por Eiján no tiene mucho fundamento, más allá de la solicitud del santuario por los franceses a las autoridades españolas, pues de todo lo visto hasta ahora se deduce con claridad que el compromiso del arzobispo sevillano era con los benedictinos franceses, la otra Orden religiosa recomendada muy eficazmente por el Excmo. Sr. Infante Duque de Montpensier, según decía en su carta al P. Lerchundi de 13 de septiembre de 1880 , ya reproducida.

\section{CONCLUSIÓN}

En la propia normativa que regulaba el proceso de exclaustración general de los regulares en España se contenían las semillas de lo que habría de ser, con el paso de los años, la restauración de los religiosos en nuestro país, merced a las propias excepciones a la regla general que contenía dicha normativa, especialmente en lo referente a los colegios de misioneros de Filipinas y la supervivencia de algunas casas de ciertos institutos religiosos, como hospitalarios y escolapios, estos últimos en mayor medida; ${ }^{100}$ a ellas pronto se unirian las de los colegios misioneros de Tierra Santa y los institutos religiosos de filipenses y paúles, ambos reconocidos expresamente por el concordato de 1851.

Añádase a estos elementos positivos el hecho, poco estudiado hasta el momento, de los grupos de religiosos exclaustrados que, al menos en los primeros años tras el desastre, mantuvieron encendida la llama de la vida religiosa, dentro de sus posibilidades, con la esperanza puesta en una vuelta a la vida regular. Entre los casos que conocemos están los capuchinos de Andalucía, quienes mantenían cierto vínculo entre ellos y seguian eligiendo provincial e

99 EIJÁN, ob. cit., pp. 153-154.

100 Contrasta la trayectoria ascendente vivida por los escolapios frente a la decadente de los hospitalarios, cuya congregación podía darse por fenecida hacia 1850 , debido principalmente a la infidelidad colectiva de sus religiosos al fin de su santa vocación; cfr. REVUELTA GONZÁLEZ, ob. cit., pp. 465-469. 
incluso usaban el hábito en privado cuando se reunían en las casas para rezar y practicar en lo posible las costumbres conventuales; ${ }^{101}$ algo parecido debía ocurrir con el círculo formado por ex carmelitas sevillanos en torno a la parroquia de S. Vicente, de la que fue cura propio el P. Rafael de Alba, nombrado provincial de su orden en 1866, último provincial de Andalucía en la época exclaustradora. ${ }^{102} \mathrm{Y}$ sin salir de Sevilla, Serrano y Ortega nos da noticia de las funciones que en 1855, ¡veinte años después de la exclaustración!, dedicaron a la Inmaculada Concepción, con motivo de la proclamación del dogma, los exclaustrados del convento franciscano de San Antonio de Padua, los de San Diego, los de San Pedro de Alcántara, los de la Merced, los carmelitas descalzos y los basilios. ${ }^{103}$

Con todos estos elementos iría tomando cuerpo el proceso restaurador de los religiosos que conoció avances y retrocesos, al albur de los cambios politicos que se fueron sucediendo a lo largo del siglo, hasta que con la restauración borbónica de 1875 se inició un movimiento de rápido desarrollo en el proceso, movimiento al que se sumó la llegada a España de las comunidades religiosas francesas, expulsadas en 1880.

Para los religiosos, una de las tareas más urgente en este proceso de restauración era la localización de edificios, a ser posible, antiguos conventos, en que pudieran instalarse las nuevas comunidades con miras a desarrollar su vida religiosa sin tener que incurrir en grandes costes de reparación y adecuación.

Uno de los lugares más solicitados fue el santuario de Nuestra Señora de Regla por su aceptable grado de conservación, gracias fundamentalmente a las grandes sumas empleadas en su restauración por los duques de Montpensier a mediados de siglo.

${ }^{101}$ Cfr. Fr. Alberto GONZÁLEZ CABALLERO, ofm cap y Hnos. JARANA MOLERO, "El convento de capuchinos de Sevilla en el siglo XIX", en Isidorianum, 6 (1917) pp. 317-342.

102 Cfr. Ismael MARTÍNEZ CARRETERO, o. carm., Los carmelitas en Sevilla. 650 años de presencia (1358-2008), Sevilla, 2009, pp. 569-571.

${ }^{103}$ Manuel SERRANO Y ORTEGA, Glorias sevillanas: noticia histórica de la devoción y culto que la M. Noble y M. Leal Ciudad de Sevilla ha profesado a la Inmaculada Concepción de la V. María..., Sevilla, 1893 (reedición: Sevilla, 2004, pp. 752-760). 
Para hacerse con lugar tan apetecible desde el punto de vista del desarrollo de la vida religiosa, tanto los franciscanos misioneros de Tierra Santa como los benedictinos franceses desplegaron cada uno sus respectivas influencias, resultando finalmente vencedores en la pugna los franciscanos españoles, quienes desde este lugar contribuirian a la restauración de la antigua provincia franciscana de Granada, ahora con el apellido de Nuestra Señora de Regla. 